\title{
Taxonomy pays for bad image
}

\section{London}

Researchers at the Natural History Museum (NHM) in London went on a one-day strike on 24 April to protest against the museum's controversial 199095 corporate plan, which proposes the loss of 51 out of 300 research and curatorial posts during the next two years. Many of the tenured posts are to be replaced with short-term fellowships (see Nature 344, 805; 26 April 1990), a move that will improve the NHM's financial health but may threaten its standing as a taxonomic research centre. On 26 April, the researchers resolved to strike again tomorrow (Friday, 4 May) if the museum's director, Neil Chalmers, refused to withdraw the plan.

Scientists at other UK museums are concerned at the damage that might be done by the new plan. Taxonomic research, in which the NHM is preeminent, is "deeply unsexy", according to Simon Conway Morris of the University of Cambridge, but is the "bedrock" of all biological research, and in the light of concern over decreasing global biodiversity the cuts come at "just the wrong time". Andrew Knoll, of the Botanical Museum of Harvard University, finds it "a little

REDUNDANCIES AT THE NATURAL HISTORY MUSEUM

\begin{tabular}{|c|c|}
\hline $\begin{array}{l}\text { Department } \\
\text { (posts lost) }\end{array}$ & Breakdown \\
\hline Botany (7) & $\begin{array}{l}\text { Research on bryophytes and diatoms } 4 \\
\text { Curation of algae \& herbaria............ } \\
\text { Taxonomic computing }\end{array}$ \\
\hline Entomology (17) & $\begin{array}{l}\text { Research on insect sounds, beetle } \\
\text { functional morphology, weevils, } \\
\text { mayflies, lacewings, caddis flies, } \\
\text { heteropteran \& coccoidean bugs. } \\
\text { bees, wasps \& microlepidoptera ...... } 12 \\
\text { Curatorial reorganization ................ }\end{array}$ \\
\hline Mineralogy (10) & $\begin{array}{l}\text { Research on mineral structure, } \\
\text { building stone and gems ................ } 4 \\
\text { Database production \& publication ...1 } \\
\text { Curation: collection management ....4 } \\
\text { Electron microscopy................... } 1\end{array}$ \\
\hline Palaeontology (10) & $\begin{array}{l}\text { Research on fossil birds, plants, } \\
\text { mammals (except primates) \& } \\
\text { Tertiary molluscs .......................6 } \\
\text { Curation of fossil invertebrates........ } \\
\text { Editorial work on Museum Bulletin.....1 }\end{array}$ \\
\hline Zoology (7) & $\begin{array}{l}\text { Research on archaeozoology, testate } \\
\text { amoebae, histology, parasitic worms } 5 \\
\text { Curation of molluscs \& lower } \\
\text { vertebrates }\end{array}$ \\
\hline & posts -51 \\
\hline
\end{tabular}

sad" that the study of biodiversity in the United Kingdom is thought so marginal that the NHM will close departments "in which they have been major contributors". Ken Joysey, curator of the Museum of Zoology at the University of Cambridge, condemned the cuts as "ludicrous".

The cuts apply to posts rather than people: researchers can, in some cases, apply for positions in the new system, which is intended in part to foster curatorship as a profession with a career structure. But in the plan as now proposed, the career opportunities are limited because each post will carry a specific civil service grade, and promotion will be possible only when senior staff depart. The danger is that young curators will leave rather than wait, which would undermine the museum's tradition of expertise founded on long service.

By abolishing tenure in favour of shortterm contract work, Chalmers will reduce the NHM's wage bill while increasing flexibility. But university-style fellowships may be inimical to museum research, built on the continuity of expert knowledge acquired over the course of a career. "Museums provide a unique environment suitable for specimen-based, non-applied research which is too often ignored by other institutions", says Philip Currie, of the Tyrrell Museum of Palaeontology in Drumheller, Alberta, and "there's no point in doing what the universities already do quite well", adds Conway Morris. But Chalmers points to the Smithsonian Institution and the American Museum of Natural History in New York as institutions with traditions of shortterm as well as permanent staff.

Chalmers hopes, by concentrating research under six general headings - biodiversity, human origins, human health, environmental quality, living resources and mineral resources - to create peaks of excellence that cancel the troughs left by the research cuts. Gone are the days, he says, when NHM could hope to cover all areas of the natural world in equal depth. But Currie criticizes the choice of subject area as "catchy buzz-words", and asks "are these not functions normally performed by government departments, universities and consulting firms?". Critics feel that Chalmers has failed to comprehend that the kind of research to be found at the NHM is unique. Cuts were bound to attract criticism, but some seem particularly inappropriate given the areas in which excellence is meant to be maximised. The Parasitic Worms section does work of potential economic importance, but its staff of six is to be halved, and the Host-Parasite Catalogue, a database started in 1922, is to be abandoned despite work to computerize it over the past two and a half years.

Responsibility for the NHM passed from the Department of Education and Science (DES) to the Office of Arts and Libraries (OAL) in July 1987. An OAL spokesperson said that contact between OAL and the museum before submission of the new corporate plan was "informal". Chalmers says that the OAL "has been very understanding and sympathetic to our scientific activities... we're in regular contact with OAL officials", but on the question of whether the OAL seeks to influence NHM policy, "the answer is clearly 'no"'.
Henry Gee

\section{Seven more nations nearly 'nuclear'}

\section{Washington}

THE 1980s were a bad decade for nuclear proliferation, with several nations developing or expanding nuclear weapons programmes, according to a report from the Carnegie Endowment for International Peace. The report found loopholes in the nuclear export controls of several industrialized nations, but found most fault with West Germany, calling it "the weak link" in the multilateral export control system."

The report says that seven nations Argentina, Brazil, India, Iraq, North Korea, Pakistan and South Africa - have all engaged in nuclear smuggling or have bent existing export requirements to build their nuclear weapons programmes. Discussion of Israel's nuclear programme is largely absent from the report, ostensibly because it was already in place by 1980 .

The seven nations are still several years away from producing nuclear bombs, but Israel, India, Pakistan and South Africa are termed "de facto nuclear powers". None of these nations has formally acknowledged the existence of a nuclear programme despite the fact that many incidents involving clandestine and quasisanctioned trade in nuclear material and technology have been documented.

The report calls upon the United States and other advanced nations to penalize states that repeatedly engage in nuclear smuggling through the threat of economic sanctions.

Seth Shulman

* Nuclear Exports: The Challenge of Control, by Leonard S. Spector, Carnegie Endowment for International Peace. Washington DC. April 1990.

\section{PUBLIC HEALTH}

\section{Radon scare doubted}

\section{London}

A group of physicists from the University of Bristol claim, in last week's issue of the Lancet, that radioactive radon gas seeping into buildings may cause leukaemia and several other cancers. The team, led by Denis Henshaw, correlated leukaemia records with average indoor radon concentrations across 14 countries. They believe that radon becomes concentrated in fat cells in bone marrow.

Michael O'Riordan, head of the National Radiological Protection Board (NRPB)'s radon programme, believes the Bristol group may have "attached too much significance to their hypothesis". Exposure to radon gives a radiation dose in the lungs 100 times that in the red bone marrow. Even if the Bristol hypothesis is correct, O'Riordan says that only about 20 out of 2,800 deaths a year from myeloid and acute leukaemia may be linked to radon. The NRPB estimate that 2,500 lung cancer deaths a year in the UK may be radoninduced.

Peter Aldhous 